\title{
Studies on the Purification of
}

\section{Antihemophilic Factor (Factor VIII)}

\section{PRECIPITATION OF ANTIHEMOPHILIC}

\author{
FACTOR BY CONCANAVALIN A
}

\author{
Lawrence Kass, Oscar D. Ratnoff, and Myron A. Leon \\ From the Departments of Medicine and Microbiology, Case Western Reserve \\ University, the Department of Medicine, University Hospitals of Cleveland, \\ and the Pathology Research Department, St. Luke's Hospital, \\ Cleveland, Ohio 44106
}

\begin{abstract}
A B S T RACT Concanavalin A precipitates antihemophilic factor from normal plasma. Combining this precipitation with other techniques, we were able to separate fractions rich in antihemophilic activity from human plasma with rapidity. The molecular weight of antihemophilic factor was estimated to be greater than 2 million. Presumably, antihemophilic factor is a large glycoprotein.
\end{abstract}

\section{INTRODUCTION}

Concanavalin A, a globulin obtained from the common jackbean plant (Canavalia ensiformis), combines readily with compounds containing sugars with unmodified hydroxyl groups at $\mathrm{C}-3, \mathrm{C}-4$, and $\mathrm{C}-6$ of the D-arabinohexopyranosyl ring $(1,2)$. Among the substances possessing these carbohydrate moieties are glycoproteins (3), which may be precipitated from solutions by the addition of concanavalin A (4-7). This property has been exploited in the separation of $\gamma \mathrm{M}$ globulins from human serum (7). The concanavalin A can be displaced from the precipitated protein by the addition of methyl $\alpha$-D-glucoside $(7,8)$ and the proteins then separated from the concanavalin A by column chromatography (7).

Hershgold and Sprawls (9) suggested that human antihemophilic factor (AHF, factor VIII) might be a glycoprotein. The experiments we shall describe agree with this concept. since concanavalin A precipitated significant amounts of antihemophilic factor from human

Dr. Ratnoff is a Career Investigator of the American Heart Association.

Received for publication 3 September 1968. plasma. Combining precipitation of antihemophilic factor by concanavalin A with other precipitation (10-12) and adsorption (13) techniques, we were able to prepare small amounts of human antihemophilic factor, containing 5-11.5 units/mg of protein, with great rapidity. Subsequent filtration through columns of agarose (9) allowed an estimation of molecular size but with such loss of activity that no additional purification was achieved.

\section{METHODS}

Cryoprecipitated fractions of human plasma were prepared from blood drawn from the antecubital veins of normal adult volunteers, using polystyrene syringes coated with silicone oil [Silicone Fluid-96 (200), General Electric Company, Waterford, N. Y.] and disposable No. 18 gauge needles. The blood was mixed with $1 / 9$ volume of sodium citrate buffer (pH 5.0, $0.13 \mathrm{M}$ with respect to citrate) in Lusteroid (cellulose nitrate) tubes coated with silicone (Dri Film, SC-87, General Electric Company) fortified with silicone oil, and centrifuged for $15 \mathrm{~min}$ at $3500 \mathrm{rpm}$. The supernatant plasma was distributed in $30-\mathrm{ml}$ aliquots into silicone-coated Lusteroid tubes, and quick-frozen by immersion in a mixture of $95 \%$ ethanol and dry ice. Immediately thereafter, the frozen plasmas were thawed for $8 \mathrm{hr}$ in a melting ice bath, and centrifuged at $10,000 \mathrm{rpm}$ for $10 \mathrm{~min}$. The supernatant plasma was discarded, and the cryoprecipitated material stored at $-70^{\circ} \mathrm{C}$ until used. A cryoprecipitate was prepared in an identical manner from a patient with known severe classic hemophilia.

Citrated plasma was prepared by similar techniques from the venous blood of a young woman with a circulating anticoagulant directed against antihemophilic factor, detected after a full-term pregnancy. The plasma was stored at $-20^{\circ} \mathrm{C}$.

Concanavalin $A$ was prepared from raw, powdered jackbean meal (Nutritional Biochemicals Corporation, Cleveland, Ohio) by the method of Sumner and Howell (4) and 
dissolved in $0.15 \mathrm{M}$ sodium chloride solution, or prepared by the method of Agrawal and Goldstein (14) as modified by Leon (7) and dissolved in $0.1 \mathrm{M}$ sodium phosphate $(\mathrm{pH}$ 6.2). The concentration of protein in the two preparations varied from 10 to $18 \mathrm{mg} / \mathrm{ml}$.

Sepharose 4- $B$ (Pharmacia Fine Chemicals Inc., New Market, N. J.), a spherical agarose gel with particle size of $30-200 \mu$ in the swollen state and approximate fractionation range for molecular weights of $1 \times 10^{4}$ to $3 \times 10^{6}(15)$, was added to sufficient barbital-saline buffer to make a thick slurry. A $33 \times 0.9 \mathrm{~cm}$ glass column was filled with barbitalsaline buffer and the outlet tubing was raised to the level of the fluid meniscus. $33 \mathrm{cc}$ of the Sepharose 4-B slurry were added intermittently to the barbital-saline buffer in the column. As the material sedimented, the outlet tubing was slowly lowered to the operating pressure of approximately $60 \mathrm{~cm}$ of water at the outlet. The column of Sepharose, 30 $\mathrm{cm}$ high by $0.9 \mathrm{~cm}$ in diameter, was washed in the cold with three column volumes of barbital-saline buffer. The void volume was determined by filtering Blue Dextran 2000 (Pharmacia Fine Chemicals Inc.), $0.2 \%$ in $10 \%$ sucrose. Other protein markers included $1 \%$ porcine thyroglobulin (Sigma Chemical Co. St. Louis, Mo.) with a molecular weight of 670,000 and $1 \%$ bovine gamma globulin (Armour Pharmaceutical Co. Kankakee, Ill.) with a molecular weight of 160,000 . The flow rate of this column was approximately $15 \mathrm{ml} / \mathrm{hr}$.

Rabbit antibody to human fibrinogen was prepared according to the method of Barnhart, Anderson, and Baher (16).

Rabbit antibody to human antihemophilic factor was prepared by injecting a mixture of equal parts of antigen, containing $40 \mu \mathrm{g}$ of protein, and Freund's complete adjuvant (Difco Laboratories, Detroit, Mich.) into the footpads and toepads of white New Zealand female rabbits. The antigen used was agarose column-purified human antihemophilic factor, separated by the method to be described. 1 month later, the same amount of antigen, without adjuvant, was injected intravenously into the same rabbits, and 7 days later blood was drawn by cardiac puncture and allowed to clot in glass tubes. The blood was kept at $4^{\circ} \mathrm{C}$ overnight and then centrifuged at $3500 \mathrm{rpm}$ for $10 \mathrm{~min}$. $1 / 9$ volume of $0.1 \mathrm{M}$ sodium oxalate and $10 \mathrm{mg}$ of calcium phosphate were added to each $\mathrm{ml}$ of serum, the mixture agitated for $10 \mathrm{~min}$ at room temperature, and the treated serum then separated by centrifugation at $3500 \mathrm{rpm}$ for $15 \mathrm{~min}$, and heated at $56^{\circ} \mathrm{C}$ for $30 \mathrm{~min}$. The serum contained an antibody directed against antihemophilic factor, as estimated by its effect upon the clot-promoting function of this substances, using a method described for the study of anti-Hageman factor antibody (17). The antiserum was frozen at $-20^{\circ} \mathrm{C}$ until needed.

Ultracentrifugal gradients of $5-20 \%$ sucrose (Mallinckrodt Chemical Company, St. Louis, Mo.) in Tris [Tris (hydroxymethyl) aminomethane, Sigma Chemical Co.] buffer $(0.15 \mathrm{M}, \mathrm{pH} 7.4)$, were prepared in cellulose nitrate ultracentrifuge cups and stored overnight at $4^{\circ} \mathrm{C}$. For use as markers in ultracentrifugation studies, $40 \mathrm{~S}$ and $58 \mathrm{~S}$ subribosomal particles prepared from rabbit reticulocyte ribosomes were provided by Dr. S. A. Armentrout, Case Western Reserve University.

Calcium chloride, magnesium chloride, manganous chloride, and cysteine were dissolved at a concentration of $0.02 \mathrm{M}$ in barbital-saline buffer, and fructose, at a concentration of $5 \%$, in the same buffer.

Crude bovine thrombin (Topical Thrombin, Parke, Davis and Co., Detroit, Mich.) was dissolved at a concentration of
$1000 \mathrm{NIH}$ units in barbital-saline and further diluted with this buffer before use.

Barbital-saline buffer was $0.25 \mathrm{M}$ sodium barbital in $0.125 \mathrm{M}$ sodium chloride at $\mathrm{pH} 7.5$ (18).

The presence of Hageman factor (factor XII), PTA (plasma thromboplastin antecedent, factor XI), Christmas factor (factor IX), antihemophilic factor ( $A H F$, factor $V I I I)$, proaccelerin (factor $V)$, Stuart factor (factor $X)$, factor VII, prothrombin (factor $I I$ ), and plasminogen, was tested by previously described methods. (18-20). The concentration of antihemophilic factor was compared with that of a standard lyophilized pool of human plasma, provided through the courtesy of Dr. David L. Aronson, of the Division of Biologics Standards, National Institutes of Health. One unit of antihemophilic factor is that amount present in $1 \mathrm{ml}$ of pooled normal human plasma (21).

The presence of fibrinogen was detected by the formation of fibrin after addition of an equal amount of bovine thrombin (10 NIH units/ml of barbital-saline buffer) to the test fraction. A sample was thought to have no appreciable coagulable protein if no particulate matter was observed $600 \mathrm{sec}$ after the addition of thrombin. Fibrinogen was also estimated by immunodiffusion in agar gel according to the method of Ouchterlony $(22,23)$ using rabbit antihuman fibrinogen.

To prepare partially purified antihemophilic factor (Table I), the cryoprecipitate separated from $180 \mathrm{ml}$ of plasma was dissolved in $8 \mathrm{ml}$ of barbital-saline buffer and divided into two parts, each of which was treated separately. In this step antihemophilic factor was usually purified 25 - to 30 -fold with respect to protein.

In duplicate, one part of the reconstituted cryoprecipitate, about $5 \mathrm{ml}$ in volume, was mixed by careful swirling with $1.34 \mathrm{~g}$ of $\boldsymbol{\beta}$-alanine (Calbiochem, Los Angeles, Calif.). This amount was sufficient to make the concentration of this amino acid 3 molal; $\beta$-alanine precipitates antihemophilic factor (12). The mixture was allowed to stand in a melting ice bath for $30 \mathrm{~min}$ and then centrifuged for $5 \mathrm{~min}$ at 10,000 $\mathrm{rpm}$. The supernatant solution was discarded. The precipitate was dissolved by tapping with a silicone-coated rod, using sufficient barbital-saline buffer to bring the volume to $5 \mathrm{ml}$. This solution was rapidly poured into an equal volume of concanavalin A solution. The mixture was stored in an ice bath for $15 \mathrm{~min}$, and the white granular precipitate which formed was separated by centrifugation at $10,000 \mathrm{rpm}$ for 5 min. The supernatant solution was discarded and the precipitate washed once with $10 \mathrm{ml}$ of cold barbital-saline buffer, recentrifuged, and dissolved by the addition of sufficient 1.0 M methyl $\alpha$-D-glucoside (Sigma Chemical Co.) to bring the total volume to $5 \mathrm{ml}$. Solution was aided by warming the mixture at $37^{\circ} \mathrm{C}$ for $5-10 \mathrm{~min}$, and tapping the precipitate with a silicone-coated glass stirring rod.

The dissolved concanavalin A-precipitated material was next added to $1.34 \mathrm{~g}$ of $\beta$-alanine, to form a solution 3 molal with respect to the amino acid, and rechilled in an ice bath for $15 \mathrm{~min}$. The precipitate which formed was separated by centrifugation at $10,000 \mathrm{rpm}$, washed once with $10 \mathrm{ml}$ of a solution of $1.0 \mathrm{M}$ methyl $\alpha$-D-glucoside in 3.0 molal $\beta$-alanine to remove any remaining traces of concanavalin $A$, recentrifuged, and dissolved in barbital-saline buffer to a final volume $1 / 10-1 / 20$ that of the original plasma.

In this state the partially purified antihemophilic factor still contained fibrinogen. This was removed by adsorption onto bentonite as suggested by Soulier (13). The mixture was added to sufficient bentonite (Pro-Labo, Rhône-Poulenc, France) to bring the concentration of this adsorbent to 20 
TABLE I

Steps in the Partial Purification of Antihemophilic Factor from Normal Plasma

Fresh citrated plasma

Frozen in ethyl alcohol-dry ice mixture

Cryoprecipitate

Dissolved in barbital-saline buffer and added to $\beta$-alanine sufficient to provide a 3.0 molal solution.

$\beta$-alanine precipitate

Dissolved in barbital-saline buffer and added to an equal volume of concanavalin $\mathrm{A}$.

Concanavalin A precipitate

Washed once with barbital-saline buffer and dissolved in $1.0 \mathrm{~m}$ methyl $\alpha$-D-glucoside and added to sufficient $\beta$-alanine to provide a 3.0 molal solution of this amino acid.

$\beta$-alanine precipitate

Washed once with 3.0 molal $\beta$-alanine. $1.0 \mathrm{M}$ methyl $\alpha$-D-glucoside, dissolved in barbitalsaline buffer and added to bentonite $(20 \mathrm{mg} / \mathrm{ml}$ of solution), and agitated for $10 \mathrm{~min}$. Centrifuged for $10 \mathrm{~min}$.

Antihemophilic factor-rich solution

Filtered through a column of Sepharose 4-B.

Partially purified antihemophilic factor fraction.

$\mathrm{mg} / \mathrm{ml}$ of solution. The bentonite tended to adhere to the sides of the silicone-coated tube if added to the solution, whereas a compact lump of bentonite could be carefully put in the tube before addition of the fraction, thus allowing maximal contact of the fraction with the bentonite. The mixture was agitated by hand at room temperature for exactly $10 \mathrm{~min}$ and centrifuged for $5 \mathrm{~min}$ at $10,000 \mathrm{rpm}$.

The supernatant solutions of the duplicate tubes were then combined and quickly concentrated $8-10$ times at $4^{\circ} \mathrm{C}$ in a pressure dialysis syringe (Amicon Corp., Cambridge, Mass.) using an Amicon UM-1 "Diaflo" membrane. The fraction was fibrinogen-free, as estimated by the absence of coagulable protein and the absence of a precipitin line when tested with rabbit antihuman fibrinogen by Ouchterlony agar gel diffusion. $2 \mathrm{ml}$ of this fraction was applied to a column of Sepharose 4-B $(33 \mathrm{~cm}$ high $\times 0.9 \mathrm{~cm}$ wide $)$, previously equilibrated with barbital-saline buffer, monitoring the pro- tein peaks of the eluate qualitatively by measuring light absorption at $280 \mathrm{~m} \mu$ with an ultraviolet absorption meter (Gilson Medical Electronics, Middleton, Wis.). $1 \mathrm{ml}$ fractions were collected and assayed immediately for antihemophilic activity and total protein.

Fractions before and after gel filtration were tested for the presence of known clotting factors and plasminogen, and subjected to disc electrophoresis on acrylamide gel according to the method of Davis (24) in a "Canalco" disc electrophoresis apparatus (Canal Industries Corp., Bethesda, Md.). The samples were stained with Amido Black or Coomassie Blue, a dye reputed to detect protein concentrations as low as $1 \mu \mathrm{g} / \mathrm{ml}(25)$, and with periodic acid-Schiff (PAS) reagent (26). The number of stainable protein components in the final purified fractions was compared with that of cryoprecipitated antihemophilic factor.

To test the specificity of the reaction of concanavalin $A$ with antihemophilic factor, aliquots of the fibrinogen-free fraction, before gel filtration, were added to equal volumes of concanavalin $\mathrm{A}$ in saline solution. The supernatant solution was saved and the miniscule precipitate which formed was washed once in barbital-saline buffer and dissolved in $1.0 \mathrm{M}$ methyl $\alpha$-D-glucoside. Both the dissolved precipitate and the supernatant solution were tested for antihemophilic activity.

In a further effort to establish the specific presence of antihemophilic factor in the fraction before gel filtration, aliquots were incubated with appropriate amounts of plasma from a patient known to have a powerful circulating anticoagulant directed against antihemophilic factor. Control samples contained mixtures of $(a)$ fresh normal plasma and the plasma containing the circulating anticoagulant, and $(b)$ the fraction or fresh normal plasma and barbital-saline buffer. After incubating $3 \mathrm{hr}$ in a $37^{\circ} \mathrm{C}$ water bath, the samples were tested for the presence of antihemophilic activity.

Attempts were made to stabilize purified antihemophilic factor by adding equal amounts of $0.002 \mathrm{M}$ magnesium chloride, calcium chloride, cysteine, and manganous chloride, $5 \%$ fructose and $100 \%$ glycerol USP to the fractions, and storing them for 5 days at $-20^{\circ} \mathrm{C}$. At the end of this time, the samples were diluted in barbital-saline buffer and assayed for antihemophilic activity. Samples were also lyophilized and stored in sealed glass containers at $-20^{\circ} \mathrm{C}$.

The fraction obtained before gel filtration were tested for the presence of contaminating concanavalin $A$ by an immune hemolysis inhibition test. ${ }^{1}$ The fraction was added to sheep cells (Southwest Laboratories, Cleveland, Ohio) sensitized with anti-sheep hemolysin (Difco Laboratories), washed, and then incubated with human complement which had been absorbed with washed sheep erythrocytes. A control set of dilutions of concanavalin A was also prepared and subjected to the same treatment as the fraction rich in antihemophilic factor. Concanavalin A inhibits the lysis of sensitized sheep cells in this complement fixation test. A reduction of hemolysis indicates the presence of this protein, and conversely, hemolysis equal to the controls signifies an absence of concanavalin A. This test can detect as little as $1 \mu \mathrm{g} / \mathrm{ml}$ of free concanavalin $\mathrm{A}$ in a test sample, but does not detect concanavalin A bound to antihemophilic factor or other glycoproteins forming soluble complexes.

Concentrated solutions of cryoprecipitated antihemophilic factor, a similar cryoprecipitate made from the plasma of a patient with known severe classical hemophilia, and fractions rich in antihemophilic factor before and after gel filtration on Sepharose 4-B were tested by the Ouchterlony

${ }^{1}$ Leon, M. A. Unpublished data. 
agar-gel immunodiffusion technique using rabbit antihuman antihemophilic factor antiserum in the center well.

Fractions rich in antihemophilic factor before gel filtration, but after bentonite treatment and concentration were subjected to ultracentrifugation by applying $0.3 \mathrm{ml}$ samples to the surface of 5-20\% sucrose gradients in aluminum layering cups (Beckman Instruments, Inc., Fullerton, California) (27). Subribosomal particles (40S and 58S) and porcine thyroglobulin (19S) were applied to separate gradients. The samples were centrifuged at $35,000 \mathrm{rpm}, 0^{\circ} \mathrm{C}$. for $3 \mathrm{hr}$. Fractions were collected, in the cold, by puncturing the bottom of the centrifuge tube. The samples were then diluted with four parts of $5 \%$ sucrose in Tris buffer $(0.15 \mathrm{M}$ $\mathrm{pH}$ 7.4). These fractions were assayed immediately for antihemophilic activity and their protein content measured.

All centrifugations were at $2^{\circ} \mathrm{C}$. Those at $3500 \mathrm{rpm}$ were performed in an International PR-2 centrifuge and those at $10,000 \mathrm{rpm}$ in the angle head of a Sorvall RC-2 centrifuge (Ivan Sorvall, Inc., Norwalk, Conn.). Ultracentrifugation was performed at $35,000 \mathrm{rpm}(100,000 \mathrm{~g}$ average $)$ in a Beckman L-2 ultracentrifuge using a SW-50L swinging bucket head.

Protein was estimated by the method of Lowry, Rosebrough, Farr, and Randall (28) or by transmittance at 260 $\mathrm{m} \mu$ and $280 \mathrm{~m} \mu$ in a Beckman model DU spectrophotometer using an absorbance meter (Gilford Instrument Company, Oberlin, Ohio).

\section{RESULTS}

Studies of antihemophilic factor prepared by concanavalin A precipitation with gel filtration. Before gel filtration, concentrates of antihemophilic factor prepared from cryoprecipitates by the technique described contained $5.0-11.5$ units of activity/mg of protein. In contrast, normal plasma, which contains about $70 \mathrm{mg}$ of protein, contains one unit of antihemophilic factor, or a specific activity of about 0.014 units/mg. Thus, the purification achieved was approximately 350 - to 800 -fold compared to the plasma from which the fractions were separated. The preparations frequently contained small amounts of proaccelerin, never more than one-half of $1 \%$ that of the original plasma, and traces of Hageman factor, PTA, and plasminogen; no fibrinogen was detectable either immunologically or by the addition of thrombin. Free concanavalin A could not be detected immunologically in the purified fractions.

The presence of antihemophilic factor in the purified fractions was detected by their capacity to correct the defect in the plasma of patients known to have classic hemophilia. That this corrective effect was attributable to antihemophilic factor was confirmed by its ready destruction by a circulating anticoagulant directed against this substance (Table II). Samples of the fraction or normal plasma, incubated with barbital-saline buffer, showed no significant loss of antihemophilic activity after incubation for $3 \mathrm{hr}$ at $37^{\circ} \mathrm{C}$. In contrast, incubation of the fraction with the plasma of a patient with a circulating anticoagulant resulted in inactivation of antihemophilic factor. Similarly, the anticoagulant
TABLE II

Incubation of AHP-Rich Fraction with Plasma Containing a Circulating Anticoagulant against Antihemophilic Factor

\begin{tabular}{lc}
\hline \multicolumn{1}{c}{ Mixture tested* } & $\begin{array}{c}\text { AHF } \\
\text { activity } \ddagger\end{array}$ \\
\hline & sec \\
A. $0.3 \mathrm{ml}$ fraction & \\
$0.6 \mathrm{ml}$ anticoagulant plasma & 127.3 \\
B. $0.3 \mathrm{ml}$ fraction & \\
$0.6 \mathrm{ml}$ barbital-saline buffer & 88.0 \\
C. $0.3 \mathrm{ml}$ normal plasma & \\
$0.6 \mathrm{ml}$ anticoagulant plasma & 113.0 \\
D. $0.3 \mathrm{ml}$ normal plasma \\
$0.6 \mathrm{ml}$ barbital-saline buffer
\end{tabular}

* After incubation at $37^{\circ} \mathrm{C}$ for $3 \mathrm{hr}$.

$\ddagger$ Clotting time in specific assay.

inactivated more than $99 \%$ of the antihemophilic activity of normal plasma during the same time interval.

The identity of the procoagulant in purified fractions with antihemophilic factor was further confirmed in studies of the effect of specific antisera. These antisera were invariably of low titer, whether because the antihemophilic factor was poorly antigenic or because only a small portion of the protein in the fractions used for immunization was antihemophilic factor (Table III). Moreover, this test did not distinguish between an effect of the antiserum upon antihemophilic factor itself and an action upon some other clot-promoting component

TABLE III

Effect of Specific Antiserum upon Antihemophilic Factor

\begin{tabular}{lc}
\hline \multicolumn{1}{c}{ Mixture* } & $\begin{array}{c}\text { AHF } \\
\text { activity } \ddagger\end{array}$ \\
\hline Normal plasma + buffer & sec \\
Normal plasma + antiserum No. 1 & 91 \\
Normal plasma + antiserum No. 2 & 116 \\
Normal plasma + antiserum No. 3 & 113 \\
Normal plasma + normal rabbit serum & 120 \\
Buffer & 95 \\
Antiserum No. 1 + buffer & 145 \\
Antiserum No. 2 + buffer & $>200$ \\
Antiserum No. 3 + buffer & $>200$ \\
\end{tabular}

* Equal mixtures of normal citrated plasma and rabbit antiserum against concanavalin-precipitated antihemophilic factor (not gel-filtered) were incubated at $37^{\circ} \mathrm{C}$ for $3 \mathrm{hr}$ and then tested for antihemophilic activity after dilution of the normal plasma 1:100 in barbital-saline buffer. The rabbit serum had been adsorbed with calcium phosphate and heated at $56^{\circ} \mathrm{C}$. $\ddagger$ Clotting time in specific assay. 
of the assay mixture; the antiserum itself prolonged the clotting time of hemophilic plasma, either by ridding it of traces of this substance or by some other inhibitory activity.

Conceivably, the precipitation of antihemophilic factor by concanavalin A was fortuitous, the clotting factor being coprecipitated with a glycoprotein. To test this, bentonite-adsorbed fractions were mixed with an equal mixture of concanavalin $\mathrm{A}$. The minute precipitate which formed contained antihemophilic factor, while none was detected in the supernatant solution (Table IV). Perhaps soluble complexes of concanavalin $\mathrm{A}$ and antihemophilic factor were present in the supernatant solution but not detected since no methyl $\alpha$-D-glucoside was present. The supernatant solution was diluted 20 -fold in barbital-saline buffer before assay to diminish the anticoagulant effect of concanavalin A. Notably, more than $90 \%$ of antihemophilic activity was lost during the reprecipitation process.

As others have found, stabilizing antihemophilic factor in dilute protein solution proved a formidable problem in these experiments. Lyophilization resulted in a loss of $50 \%$ of the antihemophilic factor activity found in the prelyophilized sample. In addition, within $30 \mathrm{~min}$ after reconstitution of the lyophilized sample, there was total disappearance of measurable antihemophilic activity. Adding $0.002 \mathrm{M}$ magnesium chloride, manganous chloride, calcium chloride, or cysteine or $5 \%$ fructose to the fraction did not stabilize its antihemophilic activity. Making the fraction $50 \%$ with respect to glycerol resulted in recovery of up to $90 \%$ of the original antihemophilic activity after 5 days storage at $-20^{\circ} \mathrm{C}$. After dilution of the glycerol-treated fraction 20 -fold in barbital-saline buffer, however, rapid decay of antihemophilic activity ensued.

After sucrose gradient ultracentrifugation of concanavalin-precipitated preparations, antihemophilic ac-

\section{TABLE IV}

Precipitation of Antihemophilic Factor by Concanavalin $A$

\begin{tabular}{lc}
\hline \multicolumn{1}{c}{ Substance tested* } & $\begin{array}{c}\text { AHF } \\
\text { activity }\end{array}$ \\
\hline & sec \\
Precipitate, undiluted & 85.8 \\
Precipitate, diluted $1 / 10$ in buffer & 102.6 \\
Supernatant solution, diluted $1 / 20$ in buffer & 122.7 \\
Buffer & 127.7 \\
\hline
\end{tabular}

* Equal volumes of fraction and concanavalin $\mathrm{A}$ were incubated $2 \mathrm{hr}$ in melting ice bath. The precipitate was dissolved in $1.0 \mathrm{M}$ methyl $\alpha$-D-glucoside and assayed for antihemophilic activity. The buffer was barbital-saline.

$\ddagger$ Clotting time in specific assay.

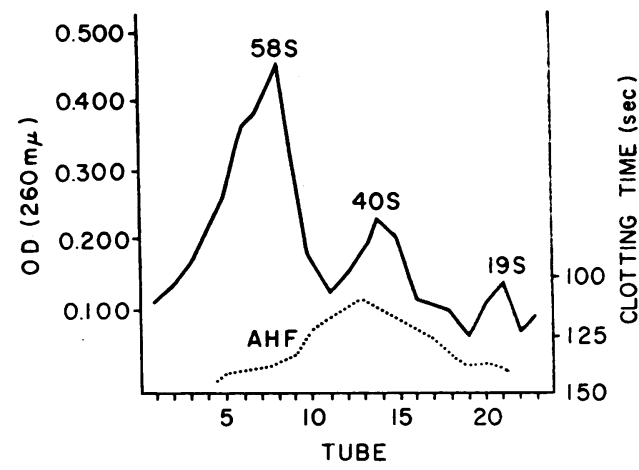

FIGURE 1 Sucrose density gradient ultracentrifugation of fraction rich in antihemophilic activity, and of $40 \mathrm{~S}, 58 \mathrm{~S}$, and 19S markers. The left ordinate records the concentration of the protein markers as a function of absorbance at $260 \mathrm{~m} \mu$. The right ordinate signifies the antihemophilic activity of different fractions of the gradient. The clotting times are recorded in seconds on a logarithmic scale and are represented by the dotted line. Tube 1 was at the bottom of the centrifuge tube, while tube 23 was at the top.

tivity was found in fractions comparable to those containing $40 \mathrm{~S}$ subribosomal particles (Fig. 1). Other physical studies could not be performed because of the low protein content of the fractions.

Studies of antihemophilic factor prepared by concanavalin $A$ precipitation and agarose gel filtration. Filtration of antihemophilic factor prepared by concanavalin A precipitation through columns of agarose separated the fraction into at least two components (Fig. 2). Approximately $45 \mathrm{~min}$ after application of the sample, antihemophilic activity appeared in association with the first protein peak, usually a few $\mathrm{ml}$ beyond the void volume; none was detectable in the second peak. Using this rapid filtration step, we were unable to increase the purification of antihemophilic factor, presumably because this agent deteriorated during the procedure; indeed, in some preparations, activity appeared to decrease. Gelfiltered antihemophilic factor contained no measurable amounts of any known clotting factor or plasminogen.

Proof that gel filtration separated antihemophilic factor from contaminating proteins was obtained by disc electrophoresis. Cryoprecipitated antihemophilic factor contained 14-16 stainable bands when subjected to electrophoresis on acrylamide gel (Fig. 3). In contrast, the electrophoretic pattern of a fraction 800 -fold purified, but not filtered through agarose, contained only 3 or 4 stainable bands, all of which were in the slow-moving gamma region. Disc electrophoresis of antihemophilic factor fractions after gel filtration did not result in visible bands when stained with Coomassie Blue. Because of the suggestion that antihemophilic factor might be a glycoprotein (9), we stained these gels with PAS. Again we were not able to detect a discrete band, but 


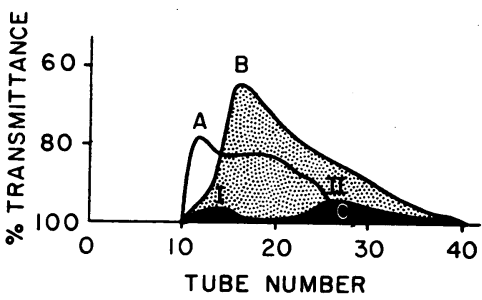

Figure 2 Elution pattern of concanavalin A-precipitated antihemophilic factor from column of sepharose 4-B. The ordinate represents per cent transmittance in a Gilford ultraviolet absorption meter. The abscissa represents the tube number; each tube contained $1 \mathrm{ml}$ of filtrate. $A$ is the void volume as determined by Blue Dextran and $B$ (stippled) is the peak of the porcine thyroglobulin marker. $C$ (solid) is the elution pattern of concanavalin A-precipitated antihemophilic factor. Peak antihemophilic activity appeared at $I$. Only trace amounts of antihemophilic activity appeared in a contaminating protein $(I I)$.

invariably a small PAS-positive area was observed at the top of the stacking gel nearest the point of application of the sample before electrophoresis. When the fraction was incorporated into a polymerizing gel, this "sample gel" stained diffusely PAS positive. These results suggest that the antihemophilic factor molecule in our

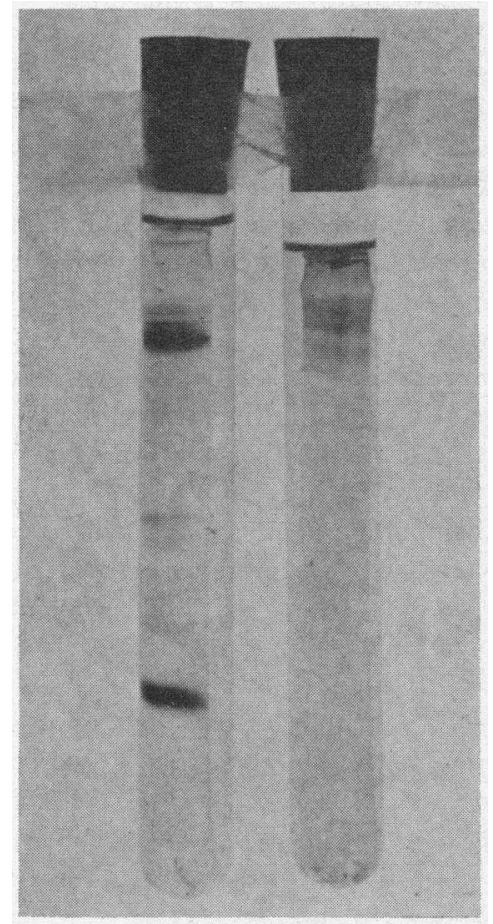

Figure 3 Disc electrophoresis in acrylamide gel. The tube at the left demonstrates electrophoretic separation of 14-16 stained bands in an untreated cryoprecipitate from a normal individual. The tube at the right illustrates 3-4 stained bands after electrophoresis of a concanavalin A-precipitated AHFrich fraction. preparations may have been too large to enter even the largest pore gel (3 $3 / 4 \%)$. In addition, incorporating antihemophilic factor in polymerizing acrylamide gel, as in the case of the sample gel, might have impeded the movement of this factor during electrophoresis.

Attempts to demonstrate the purity of antihemophilic factor by immunologic means were unsuccessful. After immunodiffusion in agar gels, four precipitin lines appeared between antibody against concanavalin A-precipitated antihemophilic factor and normal plasma, normal serum, or cryoprecipitates prepared from normal or hemophilic plasma. But no visible precipitin lines were detected between the antiserum and concanavalin A-precipitated antihemophilic factor, either before or after gel filtration.

\section{DISCUSSION}

These experiments describe a method for purifying antihemophilic factor from human plasma as much as 800 fold. The preparations obtained were not yet pure. The method used took advantage of the precipitation of antihemophilic factor by concanavalin A. Material precipitated by concanavalin $\mathrm{A}$, freed of this agent, and adsorbed with bentonite to remove fibrinogen, still contained small amounts of proaccelerin and traces of PTA, Hageman factor, and plasminogen. The preparation could be freed of detectable quantities of these contaminants by filtration through a column of agarose, but no increase in specific activity occurred, perhaps because of concomitant deterioration of the antihemophilic factor.

Our experiments provide evidence that concanavalin A precipitates antihemophilic factor. Since this plant protein reacts with carbohydrates of a particular structure $(1,2)$, its reaction with antihemophilic factor suggests that the latter is a glycoprotein, a view previously expressed by Hershgold (9). The recent observation that concanavalin A interacts with certain negatively charged polyelectrolytes such as RNA and heparin does not, in all probability, bear upon the reaction between this protein and antihemophilic factor (29). At the $\mathrm{pH}$ at which our experiments were performed, the charge on the molecules of antihemophilic factor was probably not great enough to induce nonspecific precipitation.

The data obtained provide a clue to the molecular size of antihemophilic factor, at least as it exists in cryoprecipitates. Using the method of Andrews (30), we estimate from gel filtration studies that the molecular weight of antihemophilic factor in our preparations was at least 2.0 million. This approximation assumes that the molecules of antihemophilic factor are spherical and that they are not complexed to some other component of plasma. This result seems compatible with data obtained by sucrose gradient ultracentrifugation of concanavalinprecipitated antihemophilic factor, in which this sub- 
stance was found in fractions sedimenting at approximately $40 \mathrm{~S}$ and therefore consistent with a molecular weight above 2.0 million (27). Additional estimates of molecular weight could not be made because the concentration of protein needed for such an analysis was greater than we could obtain.

In earlier studies, Lewis (31) estimated by Sephadex G-200 filtration that human antihemophilic factor had a molecular weight greater than 200,000, while Hershgold and Sprawls (32) found that the sedimentation coefficient of his purified preparations was 19. In contrast, Aronson, Preiss, and Mosesson (33) gauged the molecular weight of antihemophilic factor to be 180,000 , using an indirect method. Since our preparations of antihemophilic factor were prepared at $2^{\circ}-4^{\circ} \mathrm{C}$, from cryoprecipitated plasma, the possibility exists that the apparently high molecular weight of antihemophilic factor was the artefactual result of aggregation of smaller units. Alternatively, aggregates containing several active sites may exist in vivo, accounting for the data of Aronson et al. (33). In a subsequent paper, data will be presented suggesting that in freshly drawn plasma antihemophilic factor may indeed have a molecular weight in excess of 2 million. If this is the case, antihemophilic factor is surely one of the largest proteins in human plasma.

\section{ACKNOWLEDGMENTS}

This study was supported in part by research grants $\mathrm{HE}$ 01661 from the National Heart Institute and AI 02312 from the National Institute of Allergy and Infectious Diseases, the National Institutes of Health, the U. S. Public Health Service, and in part by a grant from American Heart Association.

\section{REFERENCES}

1. Goldstein, I. J., C. E. Holderman, and J. M. Merrick. 1965. Protein-carbohydrate interactions. I. The interaction of polysaccharides with concanavalin A. Biochem. Biophys. Acta. 97 : 68.

2. Goldstein, I. J., and R. N. Iyer. 1966. Interaction of concanavalin A, a phytohemagglutin, with model substrates. Biochem. Biophys. Acta. 121 : 197.

3. Gottschalk, A., and E. R. B. Graham. 1966. The basic structure of glycoproteins. In The Proteins. H. Neurath, editor. Academic Press Inc., New York: 2nd edition. 4: 95 .

4. Summer, P. B., and S. T. Howell. 1936. The identification of the hemagglutin of the jack bean with concanavalin A. J. Bacteriol. $32: 227$.

5. Harris, H., and E. B. Robson. 1963. Precipitin reactions between extracts of seeds of canavalia ensiformis (jack bean) and normal and pathological serum proteins. $V o x$ Sang. $8: 348$.

6. Nahamura, S., K. Tanaka, and S. Murakawa. 1960. Specific protein of legumes which reacts with animal proteins. Nature (London), 188: 144.

7. Leon, M. A. 1967. Concanavalin A reaction with human normal immunoglobulin $\mathrm{G}$ and myeloma immunoglobulin G. Science. $158: 1325$.
8. Goldstein, I. J., and L. S. Lucy. 1965. Protein-carbohydrate interaction III. Agar-gel diffusion studies on the interaction of concanavalin $A$, a lectin isolated from jack bean, with polysaccharides. Arch. Biochem. Biophys. $111: 407$.

9. Hershgold, E. J., and S. Sprawls. 1967. Native and purified Factor VIII: Molecular and electron microscopical properties and a comparison with hemophilic plasma. Fed. Proc. 26: 488.

10. Pool, J. G., and J. Robinson. 1959. Observations on plasma banking and transfusion procedure for haemaphilic patients using a quantitative assay for antihaemophilic globulin (AHG). Brit. J. Haematol. 5: 24.

11. Pool, J. G., E. J. Hershgold, and A. R. Pappenhagen. 1964. High potency antihemophilic factor concentrate prepared from cryoglobulin precipitate. Nature (London). 203: 312 .

12. Wagner, R. H., W. D. McLester, M. Smith, and K. L. Brinkhous. 1964. Purification of antihemophilic factor (Factor VIII) by amino acid precipitation. Thromb. Diath. Haemorrh. 11 : 64.

13. Soulier, P. 1959. Un novel adsorbant des facteurs de coagulation: la bentonite. Rev. Hematol. 14: 26.

14. Agrawal, B. B. L., and I. J. Goldstein. 1965. Specific binding of concanavalin A to cross-linked dextran gels. Biochem. J. $96: 23 c$.

15. Deutermann, H. 1968. Gel chromatography. SpringerVerlag New York Inc., New York.

16. Barnhart, M. I., G. F. Anderson, and W. J. Baher. 1967. Immunochemical studies on proteins important in blood coagulation. Thromb. Diath. Haemorrh. 8: 21.

17. Smink, M. McL., T. M. Daniel, O. D. Ratnoff, and A. B. Stavitsky. 1967. Immunologic demonstration of a deficiency of Hageman factor-like material in Hageman trait. J. Lab. Clin. Med. 69: 819.

18. Ratnoff, O. D., and E. W. Davie. 1962. The purification of activated Hageman factor (activated Factor XII). Biochemistry. $1: 967$.

19. Seibert, R. H., A. Margolius, Jr., and O. D. Ratnoff. 1958. Observations on hemophilia, parahemophilia, and coexistent hemophilia and parahemophilia. Alterations in the platelets and the thromboplastin generation test. J. Lab. Clin. Med. 52: 449.

20. Prentice, C. R. M., R. T. Breckenridge, and O. D. Ratnoff. 1967. Studies on the conversion of prothrombin to thrombin: with notes on the cation requirement for this reaction. J. Lab. Clin. Med. 69: 229.

21. Ratnoff, O. D., R. E. Botti, R. T. Breckenridge, and A. S. Littell. 1964. Some problems in the measurement of antihemophilic activity. In The Hemophilias. $\mathrm{K}$. M. Brinkhous, editor. University of North Carolina Press, Chapel Hill. 3.

22. Ouchterlony, Ö. 1964. Gel-diffusion techniques. In Immunological Methods. J. F. Ackroyd, editor. F. A. Davis Company, Philadelphia. 55.

23. Wieme, R. J. 1959. An improved technique of agar-gel electrophoresis on microscopic slides. Clin. Chim. Acta. 4: 317 .

24. Davis, B. 1964. Disc electrophoresis II. Method and application to human serum proteins. Ann. N.Y. Acad. Sci. 121: 404.

25. Chrambach, A., R. A. Reisfeld, M. Wyckoff, and J. A. Zaccari. 1967. Procedure for rapid and sensitive staining of protein fractionated by polyacrylamide gel electrophoresis. Anal. Biochem. 20: 150.

26. Clarke, J. T. 1964. Simplified 'disc' (polyacrylamide gel) electrophoresis. Ann. N. Y. Acad. Sci. 121: 428. 
27. Martin, R. G., and B. N. Ames. 1961. A method for determining the sedimentation behavior of enzymes: application to protein mixtures. J. Biol. Chem. 236: 1372

28. Lowry, O. H., M. J. Rosebrough, A. L. Farr, and R. J. Randall. 1951. Protein measurement with the Folin phenol reagent. J. Biol. Chem. 193: 265.

29. Doyle, R. J., E. E. Woodside, and C. W. Fishel. 1968. Protein-polyelectrolyte interactions. The concanavalin A precipitin reaction with polyelectrolytes and polysaccharide derivatives. Biochem. J. 106: 35.

30. Andrews, P. 1962. Estimation of molecular weights of proteins by gel filtration. Nature (London). 196: 36.
31. Lewis, J. H. 1964. Separation and molecular weight estimation of coagulation and fibrinolytic proteins by Sephadex gel filtration. Proc. Soc. Exp. Biol. Med. 116: 120.

32. Hershgold, E. J., and S. Sprawls. 1966. Molecular properties of purified human, bovine, and porcine antihemophilic globulins (AHG). Fed. Proc. $25: 317$.

33. Aronson, D. L., J. W. Preiss, and M. W. Mosesson. Molecular weights of Factor VIII (AHF) and Factor IX (PTC) by electron irradiation. Thromb. Diath Haemorrh. $8: 270$. 